\title{
Brand recognition in television advertising: The influence of brand presence and brand introduction
}

\author{
Authors: \\ Charlene Gerber ${ }^{1}$ \\ Marlize Terblanche-Smit ${ }^{2}$ \\ Tracey Crommelin ${ }^{3}$ \\ Affiliations: \\ ${ }^{1}$ Department of Business \\ Management, Stellenbosch \\ University, South Africa \\ ${ }^{2}$ Business School, \\ Stellenbosch University, \\ South Africa \\ ${ }^{3}$ Department of Marketing \\ and Retail Management, \\ University of South Africa, \\ South Africa
}

\section{Correspondence to:}

Marlize Terblanche-Smit

Email:

marlize.terblanche-smit@ usb.ac.za

Postal address:

Private Bag X1, Matieland

7602 , South Africa

Dates:

Received: 08 Aug. 2013

Accepted: 06 Sept. 2013

Published: 09 May 2014

How to cite this article: Gerber, C., TerblancheSmit, M. \& Crommelin, T., 2014, 'Brand recognition in television advertising: The influence of brand presence and brand introduction', Acta Commercii 14(1), Art. \#182, 8 pages. http://dx.doi. org/10.4102/ac.v14i1.182

\section{Copyright:}

(C) 2014. The Authors. Licensee: AOSIS

OpenJournals. This work is licensed under the Creative Commons Attribution License.
Purpose: To assess the relationship between brand recognition and brand presence and brand introduction.

Problem investigated: Brand recognition and recall are established advertising effectiveness measurements to assess brand awareness. Of particular interest is whether encoding of brand information as measured by brand recognition is influenced by brand presence and brand introduction.

Design/methodology/approach: A meta-analysis was performed on responses to 25 television advertisements, gathered from 50000 respondents.

Findings: The findings indicated a positive linear relationship between brand presence and brand recognition but a negative linear relationship between brand introduction and brand recognition, whilst brand introduction and brand presence predicted variance in brand recognition.

Value of research: The researchers concluded that a brand should be present in an advertisement for about two-thirds of the time for optimum brand recognition.

\section{Introduction}

Organisations have learned that the ability to communicate effectively and efficiently with their target markets is critical to their success; advertising therefore occupies an important place in the framework of modern-day marketing. A strategic marketing communication plan is one of the key elements in integrated marketing communications; it allows marketers to build a synchronised communication strategy that reaches every market segment with a single, unified message (Czinkota \& Ronkainen 2001; Egan 2007; Shimp 2010). Researchers and practitioners concur that the task of marketing communications is to inform, persuade and remind consumers (directly or indirectly) about the products or brands that companies offer. Mass media advertising has long been the cornerstone of most brand-building efforts (Joachimsthaler \& Aaker 1997; Ouwersloot \& Duncan 2008). Advertising represents the voice of a brand and is a means by which a brand can establish a dialogue and build relationships with customers (Kotler \& Keller 2009).

One of the major reasons for the growing importance of advertising over the past decade is that advertising plays a major role in the process of developing and sustaining brand equity (Belch \& Belch 2004; Shimp 2010). Customers need information to be able to choose between alternative brands (O'Guinn, Allen \& Semenik 2009; Strydom, Jooste \& Cant 2000). A brand is often a company's most valuable asset because it provides customers with a way of recognising and specifying a particular product, should the customers want to choose it again or recommend it to others. A brand is essentially a marketer's promise to deliver a specific set of features, benefits and services consistently to the consumer (Kotler \& Keller 2009). Brands serve significant communication functions and, in doing so, establish beliefs amongst consumers about the attributes and general image of a product (Hoffman 2003; Laforet 2010).

Consumers are bombarded with increasing marketing messages about brands (McKay-Nesbitt et al. 2011). Fragmentation and rising costs are also inhibiting marketing through traditional mass media like television (Joachimsthaler \& Aaker 1997). Consequently, marketers are constantly faced with the challenge to build brand awareness both economically and efficiently in the minds of consumers (Aaker 2010). One could thus assume that the building of strong brands begins with creating brand awareness (Hauser 2011; Ye \& Van Raaij 2004), so that consumers are able to identify a brand through brand recognition or recall performance (Stapel 1998). An investigation of the relationship between brand presence and brand recognition, as well as between brand introduction and brand recognition, can contribute to the understanding of overall brand recognition in television advertising. 


\section{Significance of brand awareness}

One of the major goals of marketing is to generate and maintain brand awareness (Macdonald \& Sharp 2000). Brand awareness refers to the strength of a brand's presence in the consumer's mind (Aaker 2010; Brewer \& Zhao 2010) and is a function of the number of brand-related exposures and experiences accumulated by the consumer. Anything that causes the consumer to notice and pay attention to the brand can increase brand awareness, at least in terms of brand recognition.

Brand awareness has been argued to have important effects on consumer decision-making, since consumers choose brands that are familiar to them (Hoyer \& Brown 2001; Macdonald \& Sharp 2000). Brand awareness has been shown to affect perceptions (Aaker \& Joachimsthaler 2000; Brewer \& Zhao 2010) and is an important choice tactic for consumers facing a new decision task. Consumers who are aware of one brand in a choice set tend to sample fewer brands across a series of product trials (Hoyer \& Brown 1990; Macdonald \& Sharp 2000). Brand awareness thus provides a basis for customer affinity (Radder \& Huang 2008) and consumers therefore often assume that because a brand is familiar, it has achieved market acceptance at some level (Aaker 2010).

Brand awareness is not only about how many people are aware of a brand (Hart \& Murphy 1998); it also refers to the extent and ease with which consumers recall and recognise the brand and can identify the products and services with which it is associated (Keller 2007; Macdonald \& Sharp 2003). Brand recall relates to consumers' ability to retrieve the brand from memory when given the product category, the needs fulfilled by the category or a purchase or usage situation as a cue (Keller 2007). Brand recall thus requires consumers to generate the brand correctly from memory when given a relevant cue (Aaker 2010). Brand recognition, on the other hand, is the process of perceiving a brand as previously encountered (Hoyer \& Brown 2001), and relates to consumers' ability to conform prior exposure to the brand when given the brand as a cue (Keller 2007). Brand recognition refers to the percentage of people stating that they have heard of that specific brand (Francois \& MacLachlan 1995) and requires that consumers correctly discriminate the brand as having been seen or heard of previously (Aaker 2010).

O'Guinn et al. (2009) suggest that recognising for which brand the specific communication is developed is important in advertising effectiveness. Consumers do not recall or recognise all brands equally often or with equal ease (Tybout \& Calkins 2005). Advertising effectiveness is measured by recognition and recall, to assess whether advertising has influenced brand awareness and brand-related thoughts and feelings (Shimp 2010).

\section{Advertising effectiveness measures}

Advertising is aimed at long-term brand building and as a paid form of controlled, non-personal, outward communication. It promotes ideas, goods and services of an identifiable source aimed at a specific target market in order to inform, remind or persuade consumers to act (Percy \& Elliott 2005). The implication is that advertising is primarily communication, thereby also serving communication objectives. Both verbal and non-verbal communications are used in a goal-orientated way in order to convince a consumer of specific benefits of a product (Arens 2006; Belch \& Belch 2004). Smith, Gopalakrishana and Smith (2004) maintain that the abovementioned communication helps consumers to learn and remember brands and their benefits by repeating the message and building associations between brands, logos, images and benefits - a form of classical conditioning. Moreover, advertising is often a central element of a marketing communication plan for building brand equity (Keller 2007), and the advertising message strategy is an indication of what the marketer and advertiser wish to accomplish through the advertisement (O'Guinn et al. 2009).

Various message effects are created during the processing of advertising, namely message involvement, advertising recall and message believability (Wang 2006). For advertising to be effective, an appropriate level of consumer involvement is required. Involvement helps explain not only how consumers process advertising messages, but also how the specific information might affect consumers (Belch \& Belch 2004; Wu, Lu \& Chen 2011). Zaichkowsky (1986) first explained how involvement is built on the foundation of personal relevance. He proposed three antecedents of involvement, namely personal factors (such as personality, needs, values and interests), the object or stimuli factors (the source and content of communication) and situational factors (such as the occasion, temporal perspectives and physical surroundings). These antecedents of involvement determine the level of involvement the consumer has with the relevant product, brand and advertising message (Belch \& Belch 2004; Egan 2007). Advertising therefore works mainly by communicating a persuasive informational message to build strong brands (Heath \& Feldwick 2008; Heath, Nairn \& Bottomley 2009). High attention levels have been linked with improved recall (Gardiner \& Parkin 1990) and are, therefore, normally regarded as being important for successful communication (Rossiter \& Percy 1998; Till \& Baack 2005), particularly in the case of television advertising. Moreover, it is necessary to distinguish between advertisement recall and brand recall. Sometimes, consumers remember the advertisement but not the brand. This is mostly a risk with highly creative advertisements and unfamiliar brands. On the other hand, brand recall occurs when consumers can remember the brand name in an advertisement, which can be ascribed to message elements that encourage usefulness, such as differentiation, positioning and features (Sheinin, Varki \& Ashley 2011).

There are numerous measures of advertising effectiveness in current literature. These include measures such as attitude toward the brand (Ang \& Low 2000) and brand recall (Higie \& Sewall 1991). Brand recall and recognition literature is extensive and focuses mostly on whether these two constructs measure one or two aspects of memory (Finn 1992; Stewart \& Krishnan 2001). It seems that there is agreement that both are measures of explicit memory (Rajaram, Srinivas \& Travers 
2001; Stewart \& Krishnan 2001). Advertising effectiveness is stated as the encoding of brand information in memory. This is measured by recognition and recall. The message response involvement theory denotes that varying amounts of motivation, opportunity and ability directly affect the attention given to brand processing (Wilson \& Till 2008).

One of the most well-known advertising models, theelaboration likelihood model (ELM), purports that active or attentive processing produces attitude changes that are more predictive of behaviour than inattentive processing (Petty \& Cacioppo 1986). Specific factors are also indicated to which the changes in marketing and emphasis on the marketing communication element can be attributed. These include enormous advertising clutter, numerous technological developments, people living increasingly under time constraints and increased options offered to consumers that cause them to be unpredictably confused, excited or bored (Shimp 2009; Spilker-Attig \& Brettel 2010; Van Raaij, Strazzieri \& Woodside 2001). Large advertising budgets cannot make an advertisement successful; advertising can only succeed if advertisements gain attention and the brands that are advertised are remembered (Kotler et al. 2008).

All advertising messages require an instrument or medium to reach the target audience. Shimp (2009) argues that the term media is typically applied to advertising (i.e. television, magazines, radio, Internet, etc.), although the concept of media is relevant to all marketing communication tools (Dominick 2002). Television is often chosen by advertisers because of its ability to utilise audio and visual effects in the advertising message (Heath \& Stipp 2011). This allows for increased creativity and impact with which the advertising message can be presented (Belch \& Belch 2004). Furthermore, despite changes in the television industry, such as the ability for viewers to control their viewing of television commercials, Rubinson's (2009) research empirically argues that the effectiveness of television advertising remains significant.

According to Dovy (2013), total above-the-line advertising spend in South Africa during 2011 was R32 047.2 million, which comprised approximately $45.8 \%$ television advertising, with print advertising second at $31.5 \%$. In South Africa, television advertising allows marketers to reach a vast number of consumers, but advertising rates (i.e. the cost of advertising) in South Africa have increased significantly (Koenderman 2011). During 2008 television advertising amounted to R9964.7 million and increased to R14 683.5 million during 2011 in South Africa (Dovy 2013). With the continuous pressure on marketing managers to demonstrate the profitability of their marketing actions on an ongoing basis (Ramani \& Kumar 2008), marketers want to ensure that their costly television advertising is effective.

\section{Television advertising effectiveness}

When measuring the effectiveness of television advertising, one should keep in mind that processing of and responses to television advertising do not always occur immediately after exposure to the advertisement intervention. This is referred to as the sleeper effect. Many persuasive messages therefore do not have an initial effect, but changes in behaviour take place after a period. In general terms, this is any delayed effect that arises as a result of some intervention (Cardwell 1999). Results from a study by Berger and Mitchell (1990) show that attitudes formed on the basis of repeated advertisement exposure are more accessible from memory, and are held with more confidence than attitudes based on a single advertisement exposure. In addition, Romaniuk (2009) and Ouwersloot and Duncan (2008) believe that a television advertisement is only effective when the consumers who see the advertisement know which brand is being advertised. When measuring brand recognition, respondents are required to recognize a stimulus, which might be a word, object or image, as something they have previously seen (Keller 2007). O'Guinn et al. (2009) suggest that a strong brand presence helps to reinforce the link between the message and the brand.

Higgs (2004) suggests that the longer a brand is shown in an advertisement, the more likely respondents will be able to store that information in their memory. Results from a study by Unnava and Burnkrant (1991) support this notion and explain that attention and encoding variability contribute independently to brand name memory, suggesting that brand presence assists in reinforcing the brand name in memory. Additionally, Teixeira, Wedel and Pieters (2012) conclude that the decision to zap (fast-forward) through an advertisement depends on how the brand is presented within the advertisement. The ability of an advertisement to concentrate consumers' visual attention reduces avoidance significantly, and the likelihood that consumers will zap through an advertisement can be decreased with a 'pulsing strategy' in which brand images are shown more frequently for a shorter period of time within the advertisement instead of longer at the beginning or end. Therefore, the following hypothesis can be postulated:

H1: A positive relationship exists between brand presence and brand recognition.

According to communication theory, a television advertising message is only effective when consumers who see the advertisement know which brand is being advertised (Romaniuk 2009). Higgs (2004) suggests that good branding is fundamental in marketing communication as it is a vital component in the reinforcing process and in the positive brand associations that are formed as a result. Zigmond et al. (2009) suggest that brand recognition can be increased by showing or mentioning the brand earlier on in a television advertisement. Higgs concurs that the earlier the brand is brought into a television advertisement, the better the brand recognition may be. Although brand presence and brand introduction are conceptually related to brand recognition in the literature, the link between them has been given little consideration in empirical research. Hence, it can be postulated that: 
H2: A negative relationship exists between brand introduction and brand recognition.

From the above literature discussion, it is evident that marketing communication, and in this case specifically television advertising, serves to inform, remind and persuade consumers to purchase brands, or to influence their attitude towards a specific brand. Furthermore, the above discussion also reveals that television advertising is only effective when consumers who see the advertisement know which brand is being advertised, since effective advertisements should increase brand name awareness (Teixeira et al. 2012; Zigmond et al. 2009). Therefore, if marketers succeed in creating television advertisements that influence consumers to know and remember which brand was advertised, increasing brand awareness, even after some time, the advertising message will be more effective ( $\mathrm{O}^{\prime}$ Guinn et al. 2009; Romaniuk 2009). Moreover, if brand presence and brand introduction in television advertising are functions of effective television advertising messages, then the following hypothesis can be postulated:

H3: Brand introduction and brand presence predicts variance in brand recognition.

A basic conceptual model (see Figure 1) can be used to illustrate the functional relationship between $\mathrm{H} 1, \mathrm{H} 2$ and $\mathrm{H} 3$.

\section{Methodology}

For the purposes of this study the alcoholic beverage industry was selected, since a number of alcohol brands are included amongst the top ten strongest brands in South Africa based on brand support, brand equity and brand performance (Brandfinance 2013). Additionally, above-theline alcoholic beverage advertising spend during 2009 was R1032 million, increasing to an estimated R1730 million during 2011, which represented more than 5\% of total abovethe-line advertising spend in South Africa (ARA 2013). A meta-analysis was performed for the purposes of the study being reported here. A meta-analysis is a statistical technique for amalgamating, summarising and reviewing previous quantitative research (Tustin et al. 2005:514). For the purposes of this article, previous quantitative research was reviewed, and recognition observations were scored to create new

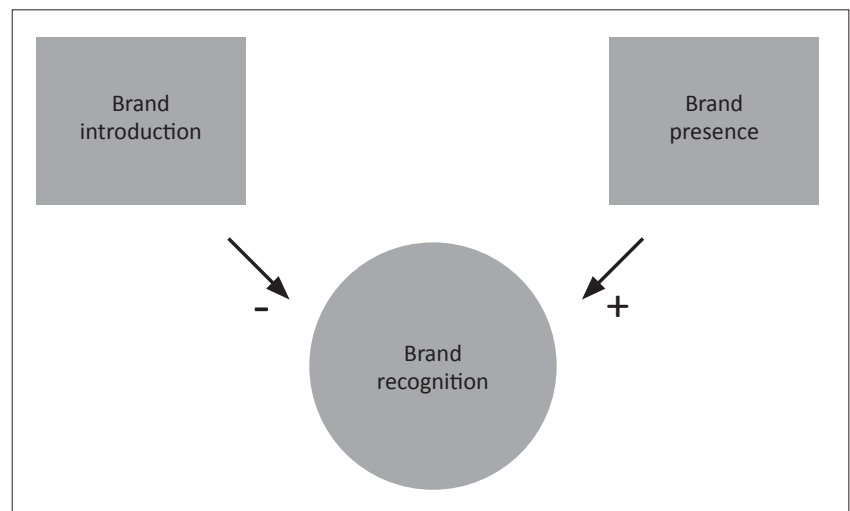

FIGURE 1: Functional relationship of brand introduction, brand presence and brand recognition. quantitative variables for brand recognition, brand recall and brand introduction. Specifically, a database containing information from about 50000 respondents, collected over a period of five years, was used. As the data from the database was used purely for academic research, the researchers did not need to purchase the data, but were granted access to the data to conduct the meta-analysis. Not only was the database large enough in terms of number of observations (i.e. respondents), but the data was also gathered from various television advertisements (i.e. 25) within the same product category, namely alcoholic beverages. The original purpose of the database was to track changes in consumer behaviour within the alcohol beverage market. Data was obtained by means of panel surveys. Respondents who were included in the research were 18 years and older, living in metro and small urban areas in South Africa. To participate in the research, respondents had to have been regular consumers of the specific product within the product category, which in this case meant that they had to have consumed the product within a week prior to being interviewed.

Since the aim of the study was to investigate brand recognition in television advertising, data pertaining to brand recognition, brand presence and brand introduction were used. For the purposes of the study, the mentioned variables were defined as follows:

- Brand presence: The percentage of time that a brand was shown in an advertisement, which included pack shots, brand logo, mentioning of the brand name and pay-off lines or slogans.

- Brand recognition: The percentage of respondents who indicated that they had seen the advertisement on television and who could link an advertisement to the correct brand.

- Brand introduction: The percentage of time that lapsed before a brand was shown in the advertisement. This included pack shots, brand logo, mentioning of the brand name and pay-off lines or slogans.

Data pertaining to the above-mentioned variables were collected for 25 advertisements. For an advertisement to be included in the study, at least 100 respondents had to have seen it on television, and only within the first six months that the advertisement was flighted on television. This was done to avoid time bias. By asking respondents whether they had seen an advertisement of a specific product category given (and describing the specific advertisement), and then asking the respondents to identify the brand, a brand recognition percentage was obtained for each advertised brand. Brand presence and brand introduction were calculated as follows:

1. Total duration of an advertisement in seconds.

2. Length of time (in seconds) that elapsed before the brand was introduced in the advertisement.

3. Length of time (in seconds) that the brand appeared in the advertisement.

These time measurements were recorded twice to ensure reliability of the results. After the recordings, brand 
introduction and brand presence for each advertisement were expressed as a percentage, as the length of each advertisement varied.

As the objective of this article was not to measure the advertising effectiveness of a specific brand within a product category, but to assess the relationship between brand introduction, brand recall and brand recognition in television advertising, generalisability is an issue to consider. Generalisability refers to the prospect of applying findings from research to other examples of the phenomenon (Malhotra 2007). According to Denscombe (2007; 2010) and Diamantopoulos and Schlegelmilch (2000), larger samples with suitably wide coverage give credibility to generalised statements made from research results. Based on these guidelines, the researchers concurred that the results obtained from the database used for the purposes of this article are generalisable to the alcoholic beverage industry in terms of marketing communication strategies, as the database was large (i.e. sample of 50000 respondents).

\section{Findings}

The 25 television advertisements that were used to investigate brand recognition in the study were flighted on television over a period of five years. For purposes of the study on which this article reports, it was assumed that the introduction and presence of brands in all advertisements were equally visible.

\section{The relationship between brand presence and brand recognition}

The relationship between brand presence and brand recognition was investigated using Pearson's productmoment correlation coefficient. Preliminary analysis was performed to ensure that there was no violation of the assumptions of normality, linearity and homoscedasticity. The results showed a strong, positive correlation between brand presence and brand recognition $(r=0.705, p<0.000)$. Hypothesis 1 was thus corroborated. The finding implied that the longer a brand is present in an advertisement, the better the brand will be recognised. This supports the findings in literature by O'Guinn et al. (2009), suggesting that the longer a brand is present in an advertisement the stronger the link between the message and the brand. Higgs' (2004) research findings were also confirmed, suggesting that increased brand presence in a television advertisement enhances storage of information in the consumer's memory. An increased brand presence in an advertisement therefore supports the process of perceiving a brand as previously encountered (Hoyer \& Brown 1990) and assist consumers' ability to confirm prior exposure to the brand when given the brand as a cue (Keller 2007).

\section{The relationship between brand introduction and brand recognition}

Hypothesis 2 claimed that a negative relationship exists between brand introduction and brand recognition.
Hypothesis 2 was tested by calculating Pearson's correlation coefficients and it was found that brand introduction has a negative linear relationship with brand recognition. The results indicated a substantial $(r=-0.508)$ and a significant relationship $(p<0.05)$ between brand introduction and brand recognition. Hypothesis 2 was thus corroborated. The finding implies that the shorter the amount of time it takes for a brand to appear in an advertisement, the more the brand will be recognised. This underlines the findings by Zigmond et al. (2009), suggesting that by showing a brand at the beginning of a television advertisement, brand recognition can be increased. Higgs (2004) also suggested that improved brand recognition could be obtained if a brand is brought into a television advertisement as early as possible. Teixeira et al. (2012) state that the likelihood that consumers will zap through an advertisement can be decreased if brand images are shown more frequently for a shorter period of time within the advertisement.

\section{Variance prediction in brand recognition}

Hypothesis 3 claimed that brand introduction and brand presence predict variance in brand recognition. Multiple regression was used to assess the ability of brand introduction and brand presence to predict brand recognition. Preliminary analysis was conducted to ensure that there was no violation of the assumptions of normality, linearity, multicollinearity and homoscedasticity. As depicted in Table 1, the total variance explained by the model as a whole was $50.5 \%$ $(F[2]=11.238, p<0.001)$. Only brand presence was found to be statistically significant (beta $=0.093, p<0.05$ ).

Table 2 indicates that brand presence and brand introduction predict the variance in brand recognition. As brand presence significantly explained unique variance in brand recognition $(p<0.005)$, further analysis of the relationship between brand recognition and brand presence was performed. Research has shown that brand recognition can be described as a quadratic function of brand presence (Till \& Baack 2005). As a result, quadratic regression was performed to examine the relationship between brand recognition and brand presence. Results indicated that the model was significant, and that $46.4 \%(F[2]=11.380, p<0.000)$ of the variance in brand recognition can be explained by brand presence.

According to Steyn et al. (1999), one of the most important objectives of a statistical investigation is to make forecasts on the basis of collected data. The majority of forecasts are based on extrapolation (Makridakis, Wheelwright \& Hyndman 1998), where: $\hat{y}=f(x)$ is a good description of the relation between the variables $x$ and $y$, and it is possible to forecast a $y$ value for a given $x$ value outside the interval-observed $x$ values, provided this relation can still be expected to apply to the $x$ value.

Therefore, by extrapolating values for brand presence, the tipping point (i.e. the point on the quadratic curve where the optimum percentage of time $(x)$ a brand should be present in an advertisement) of the quadratic function was calculated. 
TABLE 1: Regression of brand recognition, brand introduction and brand presence.

\begin{tabular}{|c|c|c|c|c|c|c|c|}
\hline \multirow[t]{2}{*}{ Predictor } & \multicolumn{3}{|c|}{ Model summary } & \multirow{2}{*}{$\begin{array}{c}\text { Analysis of variance } \\
F(\mathrm{df})\end{array}$} & \multicolumn{3}{|c|}{ Coefficients } \\
\hline & $R$ & $R^{2}$ & Adjusted $R^{2}$ & & $B$ & Beta & $T$ \\
\hline $\begin{array}{l}\text { Dependent variable: } \\
\text { Brand recognition }\end{array}$ & .711 & .505 & .46 & $11.238^{*}(2)$ & - & - & - \\
\hline Brand introduction & - & - & - & - & .093 & -.118 & -.617 \\
\hline Brand presence & - & - & - & - & 1.023 & .632 & $3.318^{* *}$ \\
\hline
\end{tabular}

*, Significant at the $95 \%$ confidence level

**, Significant at the $99 \%$ confidence level

TABLE 2: Quadratic regression of brand recognition and brand presence.

\begin{tabular}{|c|c|c|c|c|c|c|c|}
\hline \multirow[t]{2}{*}{ Predictor } & \multicolumn{3}{|c|}{ Model summary } & \multirow{2}{*}{$\begin{array}{c}\text { Analysis of variance } \\
F(\text { df) }\end{array}$} & \multicolumn{3}{|c|}{ Coefficients } \\
\hline & $R$ & $R^{2}$ & Adjusted $R^{2}$ & & $\boldsymbol{B}$ & Beta & $T$ \\
\hline $\begin{array}{l}\text { Dependent variable: } \\
\text { Brand recognition }\end{array}$ & .713 & .508 & .464 & $11.380 *(2)$ & - & - & - \\
\hline Brand presence & - & - & - & - & -0.015 & -0.525 & $-0.723 * *$ \\
\hline
\end{tabular}

*, Significant at the $95 \%$ confidence level

$* *$, Significant at the $90 \%$ confidence level

Assuming that the relation between brand recognition and brand presence is still expected to apply (Makridakis et al. 1998; Steyn et al. 1999) one can conclude that a brand should be present in an advertisement for $65.7 \%$ of the time for consumers to reach optimum brand recognition.

\section{Conclusion}

Enhanced advertising effectiveness, as measured by increased brand recognition, can be obtained by increased brand presence in an advertisement, and this assists the process of encoding brand information in memory as stated by Wilson and Till (2008). Improved brand recognition, through increased brand presence in an advertisement, supports the theory of the elaboration likelihood model (ELM), which states that by improving attentive message processing attitude, change can be effected. This will ultimately influence behaviour (Petty \& Cacioppo 1986).

From the results, it is recommended that, in order to increase brand recognition of alcoholic beverage products, marketers should increase the amount of time that the brand is shown in advertisements. The brand should also be introduced as early as possible in the advertisement. By increasing the time a brand is present in an advertisement, as well as decreasing the time that elapses before the brand is introduced in an advertisement, brand recognition will be increased, ensuring more effective marketing communication efforts.

As mentioned earlier, brand presence in alcoholic beverage advertisements is not the only factor that can influence brand recognition; factors relating to the brand also play a role. These factors might include size of the brand, awareness levels of the brand, life cycle stage of the brand as well as relevance of the brand to consumers. It is necessary to understand which of these factors influence brand recognition, and to which degree each influences brand recognition, of alcoholic beverage products through further research.

For the purposes of the study being reported here, it was assumed that the introduction and presence of brands in all alcoholic beverage advertisements were equally visible.
There are other factors relating to the actual advertisement that could also have influenced brand recognition, such as creative execution, how much the advertisement is liked by consumers or how many times a consumer has seen the advertisement. Future research could address these factors and their influence on brand recognition in alcoholic beverage advertising.

According to Shimp (2010), brand recall measures whether an advertisement has been received, but does not indicate that the message is accepted; it is therefore not predictive of sales performance. The persuasive impact of advertising should also be measured to ascertain whether an advertisement is likely to influence purchase intentions and behaviour (Belch \& Belch 2004; Shimp 2010), specifically in the alcoholic beverage industry where a large amount, namely R1.73 billion, of brand advertising is conducted via above-the-line mass advertising media (ARA 2013). As brand awareness results in consumers sampling fewer brands across a series of product trials (Hoyer \& Brown 1990; Macdonald \& Sharp 2000), and therefore provides a basis for customer affinity (Radder \& Huang 2008), future researchers could assess whether optimum brand presence levels in television advertisements will influence sales performance in branded product categories other than alcoholic beverages since there is currently much debate in the media regarding an announcement made in 2010 by South African Health Minister Aaron Motsoaledi that the government is planning extensive alcoholic beverage advertising bans (Moerdyk 2011).

This article was undertaken to assess the relationship between brand recognition, brand presence and brand introduction, with a specific focus on the alcoholic beverage industry. Results showed that a positive relationship exists between brand recognition and brand presence, but that there is a negative relationship between brand recognition and brand introduction in alcoholic beverage advertisements. The results also showed that brand introduction predicted unique variance in brand recognition and that if a brand is present for about two thirds of the advertisement, optimum brand recognition levels will be reached. The practical implications 
of this study can support marketers and creators of alcoholic beverage advertisements to develop more effective and creative executions for television advertisements. This can be done by understanding the importance of a strong brand presence in television advertisements, and by increasing the amount of time that the brand is shown. In an era of digital satellite television and personal video recorders, advertisements are frequently 'zapped', which underlines the importance of placing brands strategically early on in the advertisement, and more frequently, in order for consumers to see this when advertisements are fast-forwarded. Examples of advertisements that have successfully achieved brand recognition by using brand presence and introduction effectively in their advertising campaigns include the award winning 'The Happiness Factory' for Coca-Cola, and various automobile commercials that show the brand logo of a vehicle from different angles early on and frequently throughout the advertisement. Ultimately, television advertisement of alcoholic beverages effectiveness can be improved if an alcohol brand is introduced early in an advertisement. By putting this into practice, marketers of branded alcoholic beverages will ensure that they maximise brand recognition and thus create television advertisements that influence consumers to know and remember the brand that was advertised.

\section{Acknowledgements Competing interests}

The authors declare that they have no financial or personal relationship(s) that may have inappropriately influenced them in writing this article.

\section{Authors' contributions}

C.G. (Stellenbosch University) was the project leader, M.T.-S. (Stellenbosch University) made conceptual contributions and T.C. (University of South Africa) was responsible for the research design and data analysis.

\section{References}

Aaker, D.A., 2010, Building strong brands, Free Press, London.

Aaker, D.A. \& Joachimsthaler, E., 2000, Brand leadership, The Free Press, London.

Ang, S.H. \& Low, S.Y.M., 2000, 'Exploring the dimensions of ad creativity', Psychology and Marketing 17(10), 835-854.

ARA, 2013, Overview of alcohol beverage advertising from AdDynamix data (2013), viewed 08 August 2013, from http://www.ara.co.za/uploads/ban-on-alcohoadvertising/economic-impact-of-an-ad-ban_econometrix_ara_chapter4.pdf

Arens, W.F., 2006, Contemporary advertising, 10th edn., McGraw-Hill Irwin, New York.

Belch, G.E. \& Belch, M.A., 2004, Advertising and promotion. An integrated marketing communications perspective, 6th edn., McGraw-Hill/Irwin, New York.

Berger, I.E. \& Mitchell, A.A., 1990, 'The effect of advertising on attitude accessibility, attitude confidence, and the attitude-behavior relationship', The Journal of Consumer Research 16(3), 269-279.

Brandfinance, 2013. South Africa's 50 most valuable brands 2013, viewed 08 Augus 2013, from http://www.brandsouthafrica.com/images/pdfs/south afica_50 most valuable brands finalaugust.pdf

Brewer, A. \& Zhao, J., 2010, 'The impact of a pathway college on reputation and brand awareness for its affiliated university in Sydney', International Journal of Educational Management 24(1), 34-47.

Cardwell, M. 1999, The complete A-Z psychology handbook, Hodder and Stoughton, London.

Czinkota, M.R. \& Ronkainen, I.A., 2001, International marketing, 6th edn., Harcourt College Publishers, Orlando, FL.
Denscombe, M., 2007, The good research guide, 3rd edn., McGraw Hill, New York, NY. Denscombe, M., 2010, Ground rules for social research: Guidelines for good practice, 2nd edn., McGraw Hill, New York, NY.

Diamantopoulos, A. \& Schlegelmilch, B.B., 2000, Taking the fear out of data analysis, Thomson, London.

Dominick, J.R., 2002, The dynamics of mass communication: Media in the digital age, 7th edn., McGraw-Hill, Boston, MA.

Dovy, J., 2013, OMD's South Africa and SADC media facts 2013, viewed 08 August 2013, from http://www.omd.co.za/media_facts/FOM029_Blueprint_OMD_ mediafacts2013.pdf

Egan, J., 2007, Marketing communications, Thomson Learning, London.

Finn, A., 1992, 'Recall, recognition and the measurement of memory for printed advertisements: A reassessment', Marketing Science 11(1), 95-100. http://dx.doi. org/10.1287/mksc.11.1.95

Francois, P. \& MacLachlan, D.L., 1995, 'Ecological validation of alternative customerbased brand strength measures', International Journal of Research in Marketing 12, 321-332. http://dx.doi.org/10.1016/0167-8116(94)00022-4

Gardiner, J.M. \& Parkin, A.J., 1990, 'Attention and recollective experience in recognition', Memory and Cognition 18, 579-83. http://dx.doi.org/10.3758/ BF03197100

Hart, S. \& Murphy, J., 1998, Brands the new wealth creators, Macmillan, London.

Hauser, J.R., 2011, 'A marketing perspective on recognition-based heuristics', Judgement and Decision Making 6, 396-408.

Heath, R.G. \& Feldwick, P., 2008, '50 years using the wrong model of advertising', International Journal of Market Research 50(1), 29-59.

Heath, R.G., Nairn, A.C. \& Bottomley, P.A., 2009, 'How effective is creativity?' Journal of Advertising Research 49(4), 450-463. http://dx.doi.org/10.2501/ S0021849909091077

Heath, R.G. \& Stipp, H., 2011, 'The secret of television's success: Emotional content or rational information? After fifty years the debate continues', Journal of Advertising Research 51(1), 112-123. http://dx.doi.org/10.1086/208544

Higgs, N., 2004, 'New thinking about brands and brains', unpublished raw data, viewed January 2011, from http://www.historicalpapers.wits.ac.za/docs

Higie, R.A. \& Sewall, M.A., 1991, 'Using Recall and brand preference to evaluate advertising effectiveness', Journal of Advertising Research 31(April/May), 56-63.

Hoffman, K.D., 2003, Marketing: Best practices, 2nd edn., Thomson South-Western, Mason, $\mathrm{OH}$

Hoyer, W.D. \& Brown, S.P., 1990, 'Effects of brand awareness on choice for a common repeat-purchase product', Journal of Consumer Research 17(2), 141-148. http:// dx.doi.org/10.1086/208544

Joachimsthaler, E. \& Aaker, D.A., 1997, 'Building brands without mass media', Harvard Business Review January-February, 97-107.

Keller, K.L., 2007, Strategic brand management: Building, measuring and managing brand equity, 3rd edn., Pearson Education, London.

Koenderman, T., 2011, Ad review: South Africa and SADC media facts 2010, OMD Media Direction South Africa, Sandton.

Kotler, P., Armstrong, G., Wong, V.W.Y. \& Saunders, J.A., 2008, Principles of marketing, 5th European edn., Prentice Hall, Harlow.

Kotler, P. \& Kevin, L.K., 2009, Marketing management, 13th edn., Pearson PrenticeHall, New Jersey.

Laforet, S., 2010, Managing brands: A contemporary perspective, McGraw-Hill Education, Berkshire, UK.

Macdonald, E.K. \& Sharp, B.M., 2000, 'Brand awareness effects on consumer decisionmaking for a common, repeat purchase product: A replication', Journal of Business Research 48(1), 5-15.

Macdonald, E.K. \& Sharp, B.M., 2003, 'Management perceptions of the importance of brand awareness as an indication of advertising', Marketing Bulletin 14(2), 1-15. http://dx.doi.org/10.1016/S0148-2963(98)00070-8

Makridakis, S., Wheelwright, S.C. \& Hyndman, R.J., 1998, Forecasting: Methods and applications, 3rd edn., Wiley, New York.

Malhotra, N.K., 2007, Marketing research: An applied orientation, 5th edn., Pearson Prentice-Hall, Upper Saddle River, NJ.

McKay-Nesbitt, J., Manchanda, R.V., Smith, M.C. \& Huhmann, B.A., 2011, 'Effects of age, need for cognition, and affective intensity on advertising effectiveness' Journal of Business Research 64(1), 12-17. http://dx.doi.org/10.1016/j. jbusres.2009.09.013

Moerdyk, C., 2011, 'Banning booze ads won't cure South Africa's drinking problems', Business Day, 18 February, viewed 08 August 2013, from http://www.businessday. co.za/articles/Content.aspx?id=134723

O'Guinn, T.C., Allen, C.T. \& Semenik, R.J., 2009, Advertising and integrated brand promotion, 5th edn., Thomson South-Western, Mason, $\mathrm{OH}$.

Ouwersloot, H. \& Duncan, T., 2008, Integrated marketing communication, McGrawHill, London.

Percy, L. \& Elliott, R., 2005, Strategic advertising management, Oxford University Press, New York.

Petty, R.E. \& Cacioppo, J.T., 1986, Communication and persuasion: Central and peripheral routes to attitude change, Springer, New York. http://dx.doi. org/10.1007/978-1-4612-4964-1

Radder, L. \& Huang, W., 2008, 'High-involvement and low-involvement products', Journal of Fashion Marketing and Management 12(2), 232-243. http://dx.doi. org/10.1108/13612020810874908 
Rajaram, S., Srinivas, K. \& Travers, S., 2001, 'The effects of attention on perceptual implicit memory', Memory and Cognition 29(7), 920-930. http://dx.doi. org/10.3758/BF03195754

Ramani, G. \& Kumar, V.K., 2008, 'Interaction orientation and firm performance', Journal of Marketing 72(Jan), 27-45. http://dx.doi.org/10.1509/jmkg.72.1.27

Romaniuk, J., 2009, 'The efficacy of brand-execution tactics in TV advertising, brand placements, and internet advertising', Journal of Advertising Research 49(2), 143 150. http://dx.doi.org/10.2501/S0021849909090187

Rossiter, J.R. \& Percy, L., 1998, Advertising, communications, and promotion management, McGraw Hill, International Editions, Singapore.

Rubinson, J., 2009, 'Empirical evidence of TV advertising effectiveness', Journal of Advertising Research 49(2), 20-226. http://dx.doi.org/10.2501/ S0021849909090321

Sheinin, D.A., Varki, S. \& Ashley, C., 2011, 'The differential effect of ad novelty and message usefulness on brand judgments', Journal of Advertising 40(3), 5-17. $\mathrm{http}: / / \mathrm{dx}$.doi.org/10.2753/JOA0091-3367400301

Shimp, T.A., 2009, Advertising promotion. Supplemental aspects of integrated marketing communications, 7th edn., Dryden Press, New York.

Shimp, T.A., 2010, Integrated marketing communication in advertising and promotion 8th international edn., South Western, Hampshire.

Smith, T.M., Gopalakrishana, S. \& Smith, P.A., 2004, 'The complementary effect of trade shows on personal selling', International Journal of Research in Marketing 21(1), 61-67. http://dx.doi.org/10.1016/j.jiresmar.2003.04.003

Spilker-Attig, A. \& Brettel, M., 2010, 'Effectiveness of online advertising channels: A price-level-dependent analysis', Journal of Marketing Management 26(3/4), 343360. http://dx.doi.org/10.1080/02672571003594663

Stapel, J., 1998, 'Recall and recognition: A very close relationship', Journal of Advertising Research 38(4), 41-45.

Stewart, S. \& Krishnan, H.S., 2001, 'Memory-based measures for assessing advertising effects: A comparison of explicit and implicit memory effects', Journal of Advertising 30(3), 1-13. http://dx.doi.org/10.1080/00913367.2001.10673641

Steyn, A.G.W., Smit, C.F., Du Toit, S.H.C. \& Strasheim, C., 1999, Modern statistics in practice, Van Schaik, Cape Town.
Strydom, J.W., Jooste, C.J. \& Cant, M.C., 2000, Marketing management, 4th edn., Juta, Kenwyn.

Teixeira, T., Wedel, M. \& Pieters, R., 2012, 'To zap or not to zap: How to insert the brand in TV commercials to minimize avoidance', New Strategy 4(1), 14-22.

Till, B.D. \& Baack, D.W., 2005, 'Recall and persuasion. Does creative advertising matter?', Journal of Advertising 34(3), 47-57. http://dx.doi.org/10.1080/009133 67.2005.10639201

Tustin, D.H., Ligthelm, A.A., Martins, J.H. \& Van Wyk, H.d.J., 2005, Marketing research in practice, Unisa Press, Pretoria.

Tybout, A.M. \& Calkins, T., 2005, Kellogg on branding, Wiley, Hoboken, NJ.

Unnava, H.R. \& Burnkrant, R.E., 1991, 'An imagery-processing view of the role of pictures in print advertisements', Journal of Marketing Research 28(2), 226-231. http://dx.doi.org/10.2307/3172811

Van Raaij, F.W., Strazzieri, A. \& Woodside, A., 2001, 'New developments in marketing communications and consumer behavior', Journal of Business Research $53(2)$ 59-61. http://dx.doi.org/10.1016/S0148-2963(99)00075-2

Wang, A., 2006, Advertising engagement: A Driver of message involvement on message effects', Journal of Advertising Research 46(4), 355-368. http://dx.doi. org/10.2501/S0021849906060429

Wilson, R.T. \& Till, B.D., 2008, 'Airport advertising effectiveness. An exploratory field study', Journal of Advertising 37(1), 59-72. http://dx.doi.org/10.2753/JOA0091 3367370105

Wu, W.Y., Lu, H.Y. \& Chen, L.T., 2011, 'The moderating roles of involvement and heuristics on advertising effectiveness: A study of financial advertisements', Asian Journal of Business and Accounting 4(1), 1-21.

Ye, G. \& Van Raaij, F.W., 2004, 'Brand equity: Extending brand awareness and liking with signal detection theory', Journal of Marketing Communications 10(2), 95114. http://dx.doi.org/10.1080/13527260410001693794

Zaichkowsky, J.L., 1986, 'Conceptualising involvement', Journal of Advertising 15(2), 4-14. http://dx.doi.org/10.1080/00913367.1986.10672999

Zigmond, D., Dorai-Raj, S., Interian, Y. \& Naverniouk, I., 2009, 'Measuring advertising quality on television. Deriving meaningful metrics from audience retention data', Journal of Advertising Research 49(4), 419-428. http://dx.doi.org/10.2501/ S0021849909091090 